Tattra, Vol. 3, No. 2, July - December 2011, pp. 62-73

ISSN 0975-332X | https://doi.org/ 10.12726/tjp.6.6

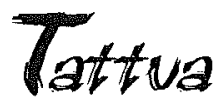

JOURNAL OF PHILOSOPHY

\title{
IMAGINATION AND PROCESS IN ANCIENT GREEK PHILOSOPHY
}

\section{Daniel Regnier}

\begin{abstract}
:
Imagination, a term derived from the common Latin translation of the Greek word phantasia, plays a very important role in the thought of A.N. Whitehead. In this paper, l examine the roots of the concept of imagination (phantasia) as it first appears in western thought in the works of Plato. In fact, Plato seems to be required to introduce the notion of imagination in his dialogue the Theaetetus precisely in order to account for process. However, Plato only provides a more extensive account of imagination in the dialogue the Sophist. With reference to the fundamental role of process, I outline Plato's understanding of imagination as he unfolds it in these two dialogues. Furthermore, 1 . attempt to indicate to what extent this concern for process is at work in the understandings of imagination that we find developed by Aristotle and the Stoics.
\end{abstract}

\section{Introduction}

Whitehead accords to imagination a very important role in his thought. In fact, it is an essential notion in his understanding of the nature speculative philosophy itself. He provides a kind of "definition" of philosophy in which the notion of imagination appears at two different levels. At the beginning of Process and Reality Whitehead 
writes, "Philosophy is the welding of the imagination and common sense into a restraint upon specialists, and also into an enlargement of their imaginations." Whitehead sees imagination as a healthy faculty, not somehow estranging us from common sense, but rather potentially allied with it, particularly insofar as it prevents thinkers from permitting their intellectual endeavors to become too narrow and perhaps positivistic in pursuit of specialization. So at a first level imagination is a tool or means by which we can prevent philosophy from loosing its proper object, an object which cannot correspond to the objects of specialists in a strict sense. Moreover, imagination is not only a means of proper philosophical inquiry but also in part its end. In the second part of the above-cited "definition" of philosophy Whitehead asserts that the philosophical communion of imagination and common sense contributes to an enlargement of imagination. That philosophy should not only exploit the imagination but also nourish it is very radical idea having very far reaching implications.

Whitehead's attention to imagination represents part of a broader revaluation of imagination, even something of a "furn" in late-modern or early $20^{\text {th }}$ century philosophy. Already thinkers like Kant and then more explicitly Fichte had made attempts to point out the essential role that imagination plays in experience after its relative neglect or even devaluation by early-modern thinkers, like Hobbes who called imagination "decaying sense" 2 or Descartes who thought that it could provide

' A.N. Whitehead, Process and Reality, New York, The Free Press, 1978, p. 17. Not only does Whitehead include imagination in his "definition" of philosophy but by way of the notion of novelty also in his "definition" of the human. He writes in Modes of Thought, "The definition of mankind is that in this genus of animals the central activity has been developed on the side of its relationship to novelty. This relationship is twofold. There is the novelty received from the aggregate diversities of bodily expressions. Such novelty requires decision as to its reduction to coherence of expression. Again there is the introduction of novelty of feeling by the entertainment of unexpressed possibilities. This second side is the enlargement of the conceptual experience of mankind. The characterization of this conceptual feeling is the sense of what might be and of what might have been. It is the entertainment of alternative. In its highest development, this becomes the entertainment of the ideal. It emphasizes the sense of importance, discussed in the previous lecture." Alfred North Whitehead, Modes of Thought, New York, The Free Press, 1938, p. 26.

2 Thomas Hobbes, Leviathan, Chapter 2: "For after the object is removed, or the eye shut, we still retain an image of the thing seen, though more obscure than when we see it. And this is it the Latins call imagination, from the image made in seeing, and apply the same, though improperly, to all the other senses. But the Greeks call it fancy, which signifies appearance, and is as proper to one sense as to another. Imagination, therefore, is nothing but decaying sense; and is found in men and many other living creatures, as well sleeping as waking." 
no certainties ${ }^{3}$. But if it is too clear that that imagination is important in philosophy, surprisingly little work has been done to provide an account of imagination in the history of philosophy or to work out from a systematic point of view what the imagination is and what precisely its role should be in epistemology and philosophy of mind. In fact, throughout much of the history of modern philosophy and even twentieth century philosophy the imagination has been treated as a sort of shadowfigure, the outlines of which seem impossible to draw with any certainty 4 .

As is quite well known, Aristotle was the first to offer a relatively comprehensive theory of imagination in Bk III, Chap. 3 of his De Anima (further very important remarks about imagination are made in III, 8-11 as well as in the De Motu Animalium and the De Memoria). And his view is, indeed, seminal for the history of European and Middle Eastern philosophy, since if is consciously adopted and elaborated by later ancient Greek and Roman philosophers and then by Arabic, Jewish and Christian thinkers in the Middle Ages. Yet few commentators remark that it was Plato who first introduced the notion of imagination in western philosophy 5 . Now, not only does Whitehead's notorious remark about philosophy

3 René Descartes, Meditations, II paragraph 7: "I know that I exist, I am asking who I be, as that I whom I know. It is very certain that the knowledge of it - taken thus precisely - does not depend on the things that I do not yel know to exist. And it does not depend, then, on any of the things that I feign with the imagination. And these very words, "I feign", warn me of my error: for I would really and truly be feigning if I were to imagine that I am something, because to imagine is nothing other than to contemplate the figure or image of a corporeal thing. But now I certainly know that I am and simultaneously that it can happen that all these images and whatever things generically are referred to the nature of the body would be nothing but dreams. What things having been noticed, I seem to be no less inept in saying that I hall imagine in order that I might more distinctly recognize who I might be, than if I were to say that I am indeed already awake and I see something true, but because I do not yet see it evidently enough I shall - the effort truly and evidently represent this itself to me. Thus do I cognize that none of the things that I can comprehend with the held of the imagination pertains to that knowledge which 10 have of me, and that the mind is very diligently to be called away from these things in order that it might itself perceive its own nature as distinctly as possible. Descartes, Meditations, trans. George Heffernan, Notre Dame/London, University of Notre Dame Presse, 1990.

4 Certain currents in $20^{\text {th }}$ century philosophy, particularly analytic philosophy have exacerbated this neglect. For example, Gilbert Ryle declared in The Concept of Mind, that "There is no special Foculty of Imagination, occupying itself single-mindedly in fancied viewings and hearings" Gilbert Ryle, The Concept of Mind London, Hutchinson, 1949.

5 See, however, A. Silverman "Plato on Phantasia", Classical Antiquity, vol. 10, 1991, 123-147 and B. Collette "Phantasia et Phantasma chez Platon", Les Études philosophiques no. 1/ 2006, 89-106. Cp. also M.W. Bundy, The Theory of Imagination in Classical and Medieval Thought, Urbana, University of Illinois, 1927; G. Watson, Phantasia in Classical Thought, Galway, Galway University Press, 1988 and J. Barnouw, Propositional Perception. Phantasia, Predication and Signe in Plato, Aristotle and the Stoics, Lanham, University Press of America, 2002. 
and footnotes give us license to direct our attention to Plato, but, as I will argue, process philosophers should be particularly interested in Plato's incipit understanding of the imagination because the founder of the Academy formulated his view of imagination in confrontation with precisely those problems which most concern Process philosophers. Thus, we might be able to go so far as to affirm that the very first occurrence of the notion of imagination in Ancient Greek Philosophy was in a broad sense an early attempt at Process philosophy.

\section{The Vocabulary of Imagination}

Before proceeding to the main argument of this paper, let me make a few remarks about vocabulary. The Greek word which came through Latin to be translated by "imagination" in English is phantasia. There has been some controversy concerning the translation of the term phantasia as "imagination". For various reasons some scholars prefer to translate it by such turns of phrase as the "faculty of representation", or the "imaging power", while others have simple preferred to leave the word phantasia untranslated. I think, however, that it is reasonable to maintain the traditional translation for two reasons. The first is based on tradition: since the Latin imaginatio, and the derivatives in European languages was the accepted translation of phantasia from late antiquity until the $20^{\text {th }}$ century, we might fail to recognize the continuity across the various philosophical positions should we attempt to introduce a new translation of phantasia at this point. The second reason is based on convenience: any translation fails at some point to adequately refer to all that its source word indicates, especially at the level of connation; indeed, even amongst Greek thinkers the word phantasia is used variously; furthermore, phantasia itself the untranslated Greek - seems to suggest the connotations associated with English words such as "fantasy" and "fancy". Consequently, "imagination" seems to be as good a translation of phantasia as any, and should be preferred because it is already in use.

Nevertheless, one should be aware that in Plato's work there is another word which could be translated as "imagination", that is, eikasia. Although this term is of great importance in Plato's thought - its relation to the notion of mimesis is quite intricate - and an exhaustive account of imagination in Plato's thought would have to devote to it a great deal of attention to the notion of ekasia, we shall not be able to direct our attention to it in this context. 


\section{The Theaetetus and Knowledge}

The Theaetetus ranks highly amongst Plato's most beloved and vexed dialogues ${ }^{6}$. Its subject matter is knowledge. Socrates begins the dialogue by examining one of his friends' students named Theaetetus, asking the young man what he is learning. Very quickly the Athenian Gadfly steers the discussion to a much more difficult question: "Now isn't it true", he asks, "that to learn is to become wiser about the thing one is learning?" (145d) The word translated by "wisdom" is here sophos that root which we find in the word philosophy, which, of course means "love of wisdom". From consideration of wisdom the interlocutors move without tarrying to a thematisation of knowledge. Socrates asks, "Isn't it the things which they know that men are wise about?" And shortly thereafter offers a tentative solution, "So knowledge and wisdom will be the same thing?" (145e), a solution which is confirmed by his young interlocutor. The project for the dialogue is hence broached. Socrates complains: "Now this is just where my difficulty comes in. I can't get a proper grasp of what on earth knowledge really is. Could we manage to put it into words? What do all of you say? Who'll speak first? (1 45e)" ${ }^{\prime \prime 7}$ Knowledge is, no doubt, one of philosophy's preferred objects.

But we should be careful to note that Plato approaches the question of knowledge from the perspective of education. At the beginning of the dialogue Socrates first intervention concerns the activities that young people pursue and how such young people turn out ${ }^{8}$. And Socrates will remind us later in the dialogue at $167 \mathrm{a}$ that we are interested in education. If the dialogue will focus on three accounts of knowledge, the question which frames the dialogue is in fact one concerning the process of becoming wiser. This fact alone already situates Plato as some kind of process philosopher.

6 Berkeley thought on the basis of the first section of the dialogue that Theaetetus anticipated and approved the main tenets of his theory of knowledge, while Richard Price, another $18^{\text {th }}$ philosopher, thought that the dialogue refuted empiricist epistemologies made popular by Berkeley and Humel It is interesting to note how many of the philosophers that Whitehead is interested in are particularly interested in the Theaetetus.

7 This translation by M.J. Levett, rev. Myles Buryeat can be found in Plato: Complete Works, ed. J. M. Cooper and D.S. Hutchinson, Indianapolis/Cambridge, Hackett Publishing, 1997. All subsequent citations from the Theaetefus are from this translation.

B Socrates first words in this dialogue are: "If Cyrene were first in my affections, Theodorus, I should be asking you how things are there, and whether any of your young people are taking up geometry or any other branch of philosophy. But, as it is, I love Athens better than Cyrene, and so I'm more anxious to know which of our young men show signs of turning out well." (143dff.) 
The three epistemological positions that will be discussed in the Theaetetus are: 1) knowledge as perception (or sense-perception) (151d-187a); knowledge as true belief (or judgment: doxa) ${ }^{9}$ (188a-201c) and 3) knowledge as true belief with an account (or justification: logos) (201 c-2 10d). It is the first position which will be of interest to us in the present study.

\section{Theaetetus and Protagorean Relativism: The Problem of Perspective}

Theaetetus responds to Socrates' challenge as follows: "It seems to me that a man who knows something perceives (aisthanesthai) what he knows, and the way it appears at present, at any rate, is that knowledge is simply perception (aisthêsis)" (15la). Socrates very promptly assimilates this position enunciated by Theaetetus to that of Protagoras. Socrates cites the Protagorean dictum, "Man is the measure of all things which are, that they are, and of the things which are not, that they are not" (152a). Plato's mentor takes Protagoras to represent a thorough-going theory of relativism. So then, elaborating Protagoras' position, Socrates gives examples of how different people perceive things differently. Accordingly, the wind, which to one person appears hot, appears cold to another.

Socrates keenly notices a slip in the way that the Protagorean position is expressed in language: "But this expression", he says, "'it appears' means 'he perceives it'?" (152b) Socrates question represents a very important juncture in the argument, for the word "it appears" is in Greek phainetai, which is an impersonal verb based on the same root as is phantasia, "imagination". It is here that we have, arguably, in verbal form the introduction of the notion of imagination. Moreover, Plato admits here that there is a level of experience which is not simply "sensation" in the terms that modern empiricists would have us conceive it - that is, as some primary simple experiences which get worked up, most often illegitimately, into a more complex yet derivative experience - but rather a level of experience involving a certain kind of judgment. The account of "appearing" or "imagination" that we get in the Theaetetus seems to be more or less equivalent to that which Plato will elaborate in the Sophist, where the notion of phantasia is used explicitly. Indeed, in the Sophist Plato provides what amounts to a definition of imagination. In the Sophist Socrates says, "what we mean by "it appears" (phainetai) is an intermixing of perception and belief

9 For a comment on the translation of the term doxa as it appears in the Timaeus, see A.N. Whitehead, Process and Reality, New York, The Free Press, 1978, note 9; 82. 
(summeixis aistheseôs kai doxês) $(264 a-b)^{10}$. Plato thus develops the idea that at least a first level - of imagination corresponds precisely to the experiencing of reality as related to the self as subject, that is, to a self which forms beliefs about what it experiences, beliefs which are in some sense evaluative. The notion of value shall not escape readers of Whitehead. For Whitehead argues that valuation is essential in human experience, but sorely neglected by much empirically oriented philosophy to the peril of "importance", that central notion in Whitehead's philosophy".

\section{Theaetetus and Heraclitean Flux: Imagination and Objective Becoming}

Let us return to the dialogue Theaetetus. Having identified Theaetetus' thesis that knowledge is perception with Protagoras' relativist position, Socrates goes one step further in making associations. He says,

[T] his, now, is certainly no ordinary theory - I mean the theory that there is nothing which in itself is just one thing: nothing which you could rightly call anything or any kind of thing. If you call a thing large, it will reveal itself as small, and if you call it heavy it is liable to appear as light, and so on with everything, because nothing is anything or any kind of thing. What is really true, is this: the things of which we naturally say that they 'are', are in process of coming to be, as a result of movement and change and blending with one another. We are wrong when we say they 'are', since nothing ever is, but everything is coming to be.

And as regards this point of view, let us take it as a fact that all the wise men of the past, with the exception of Parmenides, stand together. Let us take it that we find on this side Protagoras and Heraclitus and Empedocles; and also the masters of the two kinds of poetry, Epicharmus in comedy and Homer in tragedy. For when Homer talked about 'Ocean, begetter of gods, and Tethys their mother', he made all things the offspring of flux and motion. - Or don't you think he meant that? (152d-e)

This definition seems to be the object of Aristotle's critique in De Anima III, 3, 428 a 18-28.

" For Whitehead's understanding of "importance" see Modes of Thought, New York, The Free Press, 1938, Lecture I "Importance", p. 1-19. Cf. p. 79: "Importance arises from the fusion of the finite and the infinite ... Life degenerates when enclosed within the shackles of mere conformation. A power of incorporating vague and disorderly elements of experience is essential for the advance into novelty." 
This association of Protagoras with Heraclitus will be made even clearer further along in the dialogue. In fact, after having exhausted Theaetetus as interlocutor, Socrates provokes the young mathematician's mentor, Theodoros, to take over the defense of the position according to which knowledge is perception. At this point Socrates formulates baldly the two premises upon which he thinks the position is based: "a) that all things are in motion (Heraclitus), b) that for each person and each city, things are what they seem to them to be (Protagoras)" (168b). What we have is the combination of a epistemological position - Protagoras' relativism and a metaphysical position - Heraclitus' theory of flux. Much could be said about the coherence of such associations. Suffice it to say that Socrates seems committed to the position according to which for us to have "knowledge" there must be coherence between epistemological and metaphysical positions.

Now, if we can be certain that Whitehead sees Heraclitus' insight about flux as extremely important "first vague generalization" ${ }^{2}$, scholars do not agree on the way that Plato himself evaluates the positions that come up in the first part of the Theaetefus, Protagorean relativism and Heraclitean flux. Some think that Plato admits their veracity insofar as the world of sense and the experience of perception is concerned, but not insofar as knowledge is concerned. Others think that Plato does not accept them at all, but that, if they were true, language would be impossible. ${ }^{13}$ I think that the first of these two interpretations is to be preferred. We cannot go into the details of an interpretation of the dialogue in this context, since it would require consideration of the second and third section of the dialogue.

Suffice it to say that Plato seems to be showing in the Theaeteus that since the human being is confronted by a world of more than apparent flux and because people perceive many things, at least warm and cool winds differently, it is essential that the mind have, as it were, a "space" and a capacity to deal with this level of reality. This seems to be the position that will be confirmed in the Sophist where it is abundantly clear that there is such a thing as imagination (phantasia) which is required if not as a psychological faculty (which is what Aristotle will, it seems, ultimately assert), then at least as a capacity of cognition to go beyond mere sensation and make of raw sense data a kind of unified and meaningful experience (which can incidentally be true or false!) This capacity of imagination is necessary precisely because the sense-world is in flux, in becoming or in process.

12 A.N. Whitehead, Process and Reality, New York, The Free Press, 1978, 208. Whitehead introduces Chapter $X$ "Process" with a discussion of Heraclitus.

13 See M. Burnyeat, The Theaetetus of Plato, Cambridge, Hackett, 1990. 9. 


\section{Theaetetus, Socratic Method and Thinking: Imagination and Subjective Becoming}

But there is of course another side to the process. Not only is the world in flux but the human subject is also constantly changing. I have already mentioned how the Theaetetus is framed by the question concerning how one becomes wiser, and it might be worth remarking that we find one of the most famous passages on Socratic Method in the Theaetefus, that is, Socrates' explanation of his role as midwife (148e-151d.). From a process philosophical point of view we might say that in the Theaetetus Plato is ultimately trying to show that, given that the world is in flux, and the individual mind contributes a great deal to its immediate perceptions of the world - as the world "appears" differently to different people and to the same people at different times - and in order to become wise, we have to be aware of the way that we "think" both consciously and unconsciously.

Plato does not go so far as does Aristotle, who insists that every thought is accompanied by an image ${ }^{14}$, but he does in the late dialogues give fairly detailed accounts of the psychology of thought, that is, of discursive thought (dianoia), the kind of thinking that takes place in time. The Theaetetus, the Sophist and the Philebus form respectively a kind of series elaborating step by step an increasingly detailed view of imagination and on the basis of a richer view of imagination, of discursive thinking. So in the Theaetetus Plato underlines the fact that insofar as things "appear" to people and, what is more, "appear" variously, there must be an immediate capacity of perception that is partially judgmental or evaluative and can experience the world of flux. Imagination is at work in everyday perception and forms the basis of thought. In the Sophist Plato will show how thinking is in some sense a kind of internal dialogue (263e) and how the epistemological claims about imagination in the Theaetetus can be applied to metaphysical problems. In the Philebus Plato explains how imagination has not only an organizing and basic evaluating function, but also projects the subject into the future and is explicitly evaluative in an ethical way. Furthermore, in the Philebus Plato suggests that thinking in propositional form is like a scribe writing, a scribe who is accompanied by a craftsman, or artist who illustrates the text which is propositional thought. Discursive thought is thus given another dimension beyond language, a dimension of imagination. But not only that, it seems that discursive thought requires

14 De Anima I, 1, 403 a 8-9; III, 7, 431 a 16-17; III, 8, 432 a 8-9 and De Memoria 1, 449 b 28 -450 a 14. 
imagination. This insight seems to have a particularly Whiteheadian ring to it. In Modes of Thought Whitehead writes,

My point is that understanding is never a completed static state of mind. It always bears the character of a process of penetration, incomplete and partial. ... My thesis is that when we realize ourselves as engaged in a process of penetration, we have a fuller self-knowledge than when we feel a completion of the job of intelligence. ${ }^{15}$

\section{Conclusion}

To conclude, then, if Plato is quite often portrayed as an antagonist in the drama of Process Philosophy ${ }^{16}$, there is good reason to see him presented also in other garb, that is, as a sympathizer to the Process cause. In fact, he was the very originator of the concept of the imagination, so essential for the Process philosopher, who to a very large extent is concerned with overcoming the various early-modern philosophical models of mind and knowledge. Significantly, Plato developed his notion of imagination precisely in his struggle to adequately take into account appearances of change and flux.

Although I have only had time here to focus on Plato's introduction of imagination in the Theaetetus, while neglecting the details of his notion of imagination in the Sophist and the Philebus and making no substantial mention of Aristotle, I would in closing like to indicate very briefly how certain ideas essential to Whitehead's thought are associated in Plato and Aristotle with the imagination. Plato will associate

15 A.N. Whitehead, Modes of Thought, New York, The Free Press, 1938, 43.

16 Not least of all by Whitehead himself who writes, "The most simple doctrine about types of being is that some extreme type exists independently of the rest of things. For example, Greek philosophers, and in particular Plato, seem to have held this doctrine in respect to qualitative abstractions, such as number, geometrical relation, moral characteristics, and the qualitative disclosures of the higher sense perceptions. Namely, according to this tradition in so far as we abstract from our experience the brute particularity of happening here, and now, amid this environment, there remains a residue with self-identities, differences, and essential interconnections, which seems to have no essential reference to the passage of events. According to this doctrine, as the result of this discard of the factor of transition we rivet our attention on the eternal realm of forms. In this imagined realm there is no passage, no loss, no gain. It is complete in itself. It is self-sustaining. It is therefore the realm of the "completely real". This is the notion that has hunted philosophy. It was never far from Greek thought. Later, it transformed the Hebraic elements in Christian thought." Modes of Thought, New York, The Free Press, 1938, 67. 
imagination with action and choice in the Philebus, an association with is made extremely explicit in the section of Aristotle's De Anima and his De Motu Animalium where he tries to explain how it is at all possible that animals can move themselves. Compare Whitehead, who writes,

Mankind and the animals with analogous abilities are distinguished by their capacity for the introduction of novelty, and a practical power which can effect. The role of sense experiences consists in the fact that they are manageable ${ }^{17}$.

The imagination will function as a kind of space which receives abstract thoughts and gives them a certain concreteness, a function sketched by Plato in the Philebus and made especially clear in Aristotle's De Anima. For his part Whitehead insists that "the notion of intelligence in pure abstraction from things understood is a myth. "18. On the other hand, the imagination will also be for the ancient Greeks the place where sense perception comes to have a certain unity, an idea that suggests Whitehead's notion of concrescence (see PR). Aristotle associates imagination with a certain kind of imprecision or vagueness in the De Anima, as Plato arguably does in the Theaetetus. It is well-know that Whitehead accords a very important role to vagueness in his thought. Aristotle's claim that there is no thought without an image suggests a theory of intentionality, a theory which, once again, seems to exclude purely abstract thought. As we have seen in passing, Plato associates thought with language and language with images. Compare Whitehead, who writes,

When we examine the content of language, that is to say, the experiences which it symbolizes, it is remarkable how largely it points away from the abstractions of high-grade sensa. Its meaning presupposes the concrete relations of real events happening and issuing from each other. ${ }^{19}$

Aristotle and later Plotinus will associate imagination with memory. While Whitehead does not make this connection explicit he does associate memory with language, which as we have seen, the ancient Greek philosophers associate with imagination. Whitehead explains, "Language is expression from one's past into one's present. If is the reproduction in the present of sensa which have intimate association with the realities of the past. [...] an articulated memory is the gift of language., ${ }^{20}$ 
Ancient Greek philosophers conceive of imagination in a very broad sense, such that it covers functions strikingly that are characteristic of the Process philosophical approach to reality. It would seem, then that in his or her dialogue with the history of philosophy the Process Philosopher should be particularly interested in Ancient Greek notions of imagination. 